\title{
Changes During Growth in Cell Wall Components of Berseem Clover Under Different Cutting Treatments in a Mediterranean Region
}

\author{
Giuditta De Santis ${ }^{1 *}$, Anna Iannucci ${ }^{1}$, Eugenio Chiaravalle ${ }^{2}$ \\ ${ }^{1} C R A$ - Istituto Sperimentale per le Colture Foraggere \\ Via Napoli 52, 71100 Foggia, Italy \\ ${ }^{2}$ Istituto Zooprofilattico Sperimentale della Puglia e della Basilicata \\ Via Manfredonia 20, 71100 Foggia, Italy
}

Received: 2 December 2006. Accepted: 18 March 2007.

\begin{abstract}
Forage digestibility of berseem clover (Trifolium Alexandrinum L.) is influenced by plant cell wall composition. This study was conducted to evaluate the effects of different cutting treatments on cell-wall components of the herbage and plant fractions in two Mediterranean berseem genotypes during growth and to examine the relationship between digestibility and cell wall components in these plant fractions. Cutting treatments were initiated at sixth internode elongation (A) and early flowering (B) and there was an uncut control treatment (C). Spring growth of genotypes of Egyptian (cv. Giza 10) and Italian (cv. Sacromonte) origins was harvested in each of two years beginning 196 days after sowing and thereafter every 6 days (twelve harvests in total) to measure cell wall components. Neutral detergent fibre (NDF), acid detergent fibre (ADF) and acid detergent lignin (ADL) concentrations were determined for leaf, stem, and total forage of each cultivar at each harvest. Without defoliation, NDF, ADF and ADL concentrations of herbage increased linearly to a maximum of 528, 375 and $84 \mathrm{~g} \mathrm{~kg}^{-1} \mathrm{DM}$, respectively, by 220 days after planting, when plant height reached maximum values, then plateaued until 257 days after planting. Plant parts differed in cell-wall concentration, with stems being of higher fibre components than leaves, in the two cutting treatments. Herbage and plant fraction fibre concentrations were negatively correlated with digestibility for all cutting treatments. Defoliation induced a reduction in fibre concentrations and plant height, although a rapid regrowth was observed after cutting, in both treatments A and B. However, delaying defoliation to the early flowering stage (B) increased fibre components concentrations both at cutting time and during the growing season and significantly reduced the regrowth height. Conversely, plants cut at the sixth internode elongation (treatment A) showed lower concentrations of fibre fractions than initiating cutting at early flower (treatment B). Therefore, harvest management in which cuts are applied at the stage of sixth internode elongation appears to be the most favourable for obtaining forage of lower fibre content in berseem clover grown in Mediterranean regions.
\end{abstract}

Key-words: ADF, ADL, Berseem clover, cultivar, cutting treatment, NDF.

\section{Introduction}

Most variation in digestibility and voluntary intake of herbage by ruminants is caused by differences in cell walls concentration and composition. In alfalfa Buxton and Hornstein (1986) identified cell-wall concentration and proportion of lignin within cell walls as the major limitations to herbage and stem in vitro dry matter (DM) digestibility.
The utilization by ruminants of cell wall components is different for various plant fractions and development stages, as well as for different types of cell walls (Chesson et al., 1986). Previously, we reported that cutting treatment and development stage at cutting had the greatest effects on DM partitioning and changes in nutritive value of berseem clover (De Santis et al., 2004). In our material, the nutritive value of 
the herbage, such as crude protein $(\mathrm{CP})$ concentration and in vitro organic matter digestibility (IVOMD) values, is largely influenced by leaf-stem ratio and the nutritive value of the stem.

Plant maturity is the major factor affecting morphology and determining forage quality. As plants advance in maturity, the leaf/stem ratio decreases. Additionally, cell-wall concentration within stems, and usually within leaves, increases and the proportion of cell solubles decreases. This, indirectly decreases the digestibility of total herbage. Generally, among both grasses and legumes, the digestibilities of both leaves and stems decline with increasing maturity (Jung and Vogel, 1992). However, Albrecht et al. (1987) found that alfalfa stems increased in cell wall and lignin contents with increasing maturity, but alfalfa leaves maintained relatively constant composition across maturity levels. Thus, alfalfa stem digestibility decreases considerably with increasing maturity, whereas digestibility of alfalfa leaves is little affected.

Cell wall constituents analysed as fibre insoluble in a neutral detergent solution (NDF), were shown to consist of cellulose, hemicellulose, and lignin, with lignin and cellulose being combined in acid detergent fibre (ADF). Thus, neutral-detergent-fibre (NDF) is an estimate of total cell-wall concentration for forages and results the fraction best correlated to digestibility (Goering and Van Soest, 1970). However, also the acid detergent fibre (ADF) and acid detergent lignin (ADL) fractions are reported to have statistical association with forage digestibility. For herbage of alfalfa (Medicago sati$v a$ L.), birdsfoot trefoil (Lotus corniculatus L.), and red and white clover, Buxton and Hornstein (1986) reported that correlation coefficients ranged from -0.82 to -0.95 between NDF concentration and IVDDM concentration, from -0.62 to -0.92 between ADF concentration and IVDDM concentration, and from -0.40 to -0.75 between ADL and IVDDM concentration. In four clover pecies Brink and Fairbrother (1994) found negative correlations between cell-wall components and in vitro DM digestibility, during primary spring growth. For berseem clover, they reported that correlation coefficients between NDF concentration and in vitro DM digestibility were -0.85 , for herbage, and -0.42 and -0.91 for leaf and stem fraction, respectively.
However, they found moderate or no associations between herbage and plant fraction lignin concentration and in vitro DM digestibility.

Furthermore, correlations between forage quality, and morphological and agronomic traits have been reported. For alfalfa, negative correlations were reported for lignin with leaf-tostem ratio and stem height (Kephart et al., 1989, 1990). Information is still lacking, however, regarding the effects of different cutting treatments on changes in cell-wall composition of berseem clover and its relationship to digestibility. Therefore, the objectives were to determine the changes in cell-wall composition of the herbage and leaf and stem components of two berseem genotypes grown under different cutting treatments and to examine the association between digestibility and cell-wall components in these plant fractions, so as to develop management approaches for harvesting a forage with higher digestibility and lower fibre content.

\section{Materials and methods}

\subsection{Plant material}

Two berseem clover cultivars of different geographical origin, "Giza 10" (Egyptian) and "Sacromonte" (Italian) and differing in physiological traits (Iannucci et al., 1996), previously evaluated for forage yield and nuritive value, were used in this study. Planting, development and cutting treatments used, have been previously described by De Santis et al. (2004). Briefly, field experiments were conducted during two growing seasons (1992-93 and 1993-94), in Foggia, southern Italy $\left(41^{\circ} 31^{\prime} \mathrm{N}, 15^{\circ} 33^{\prime} \mathrm{E}\right)$. In mid-October of each year, seedlings of each of the two cultivars were transplanted to 108 field plots of $0.45 \mathrm{~m}^{-2}$ (three rows $0.5 \mathrm{~m}$ long and $30 \mathrm{~cm}$ apart) with 10 plants per row. The experimental design was a randomized complete block with a split-split-plot arrangement of treatments in three replicate blocks. Cultivars were main-plots, cutting treatments sub-plots and harvest dates sub-sub-plots.

Cutting treatments were applied at three different plant ages: sixth internode elongation (A), early flowering (B) and uncut control (C). Starting from the fifth internode elongation of the main shoot (about 196 days after planting DAP) until unharvested plants reached the late 
seed pod stage of development (about 257 DAP), 12 destructive harvests were made at 5to 6-day intervals, in all cutting treatments. During the experimental period, plants of each cultivar were defoliated twice to ground level in both treatments A (about 202 and 232 DAP, harvest 2 and 7, respectively) and B ( about 214 and 238 DAP, harvest 4 and 8, respectively). At each harvest, plants of the central row of a plot were individually separated into stems, leaves, heads, crowns and roots and evaluated for forage and seed yield (Iannucci, 2001). At each sampling the length of the main shoot from soil level was also recorded. For quality analysis of this study, the leaf and stem fractions were used.

\subsection{Chemical analyses}

Cell-wall components was determined on herbage, leaf and stem fractions, previously evaluated, on twelve dates in 1993 and 1994. Three replicates per harvest date for each treatment were analysed. The forage samples were dried at $60{ }^{\circ} \mathrm{C}$ for $48 \mathrm{~h}$, weighed, and ground to pass a 1-mm screen prior to laboratory analysis. Herbage and plant fraction NDF, ADF and ADL concentration were predicted using the Near Infrared Reflectance methodology (Technicon InfraAlyzer NIR450, Mandel Scientific Company, Ltd., Guelph, Ontario) after suitable prediction equations were developed (Marten et al., 1984). In 1993 and 1994, 90 and 80 samples, respectively, were selected from all samples using the SELECT program described by Shenk and Westerhaus (1991) and then chemically analyzed for NDF, ADF and ADL by the methods of Goering and Van Soest (1970). These 170 samples were used to create a calibration equation to predict the constituents of all samples collected in the two years. The coefficients of determination of multiple regression $\left(\mathrm{R}^{2}\right)$ for NDF, ADF and ADL were 0.97, 0.95 and 0.93, respectively. All analyses were expressed on a dry matter (DM) basis. In this study, NDF was used to estimate cell wall concentration. It is recognized that NDF understimates true cell wall concentration, because pectins are solubilized during the procedure. Measurement of sample IVOMD concentration has been described previously (De Santis et al. 2004).

\subsection{Statistical analyses}

Initially, an analysis of variance (ANOVA) was carried out with the whole data set to test statistical significance of cultivars, cutting treatments and harvest dates, across years. All response variables were analysed by mixed-models analysis of variance, assuming years to be random effects and cultivars, cutting treatments and harvest dates to be fixed effects. This ANOVA identified that there were significant $(\mathrm{P} \leq$ 0.01 ) cutting treatments, harvest dates and interactions effects. Subsequently, data for each cutting treatment were analysed separately, with years as random effect, and cultivars and harvest dates as fixed effects, in the model. Several year $\mathrm{x}$ harvest dates interactions were detected when data were analysed across years. However, the growth patterns were broadly similar between years, so data from each harvest across years were combined for analyses and presentation. Means were separated using Fisher's protected LSD $(\mathrm{P}<0.05)$ when F-tests were determined to be significant (Steel and Torrie, 1980). Simple correlations were calculated between cell wall components of herbage and leaf and stem fractions and IVOMD values reported previously (De Santis et al. 2004).

\section{Results}

Analysis of variance revealed a significant $(\mathrm{P}<$ 0.01) effect of harvest date for almost all the traits in all cutting treatments (Tab. 1). Harvest date affected all cell-wall components, except herbage and leaf ADL in treatments A, and leaf $\mathrm{ADF}$ in treatment $\mathrm{B}$, being the most important factor in influencing herbage cell-wall components, during the growth. Differences between cultivars were significant $(\mathrm{P}<0.05)$ for most of the traits for herbage, and leaf and stem components in treatments $\mathrm{A}$ and $\mathrm{B}$, but only for ADF of the herbage, in treatment $C$, indicating that there was no difference between the two cultivars when no forage harvest was applied. Differences between years were significant $(\mathrm{P}<0.05)$ for all traits for herbage and leaf and stem components, indicating that cellwall components of berseem clover depended on the year. However, most of the two-factor interactions (year $\mathrm{x}$ cultivar) and (cultivar $\mathrm{x}$ harvest) shown in Table 1 were not significant, indicating that there was no interaction of the cultivars with the harvest dates and weather conditions. 
Table 1. Statistical significance of $F$ ratios from the analysis of variance for neutral detergent fibre (NDF), acid detergent fibre (ADF) and acid detergent lignin (ADL) of herbage, leaf and stem components, and plant height, for each cutting treatment.

\begin{tabular}{|c|c|c|c|c|c|c|c|c|c|c|c|c|}
\hline \multirow[b]{2}{*}{ Treatment $\dagger$} & \multirow[b]{2}{*}{ Variable } & \multicolumn{5}{|c|}{ Herbage } & \multicolumn{3}{|l|}{ Leaf } & \multicolumn{3}{|l|}{ Stem } \\
\hline & & df & NDF & $\mathrm{ADF}$ & $\mathrm{ADL}$ & $\mathrm{NDF}$ & $\mathrm{ADF}$ & $\mathrm{ADL}$ & $\mathrm{NDF}$ & $\mathrm{ADF}$ & $\mathrm{ADL}$ & $\begin{array}{l}\text { Plant } \\
\text { height }\end{array}$ \\
\hline \multirow[t]{7}{*}{$A$} & Year (Y) & 1 & $* *$ & $* *$ & $* *$ & $* *$ & $* *$ & $* *$ & $* *$ & $* *$ & $* *$ & NS \\
\hline & Cultivar (C) & 1 & $* *$ & $* *$ & $*$ & $* *$ & NS & $* *$ & $*$ & $* *$ & $* *$ & $* *$ \\
\hline & $\mathrm{Y} \times \mathrm{C}$ & 1 & NS & NS & NS & NS & $*$ & NS & NS & NS & NS & NS \\
\hline & Harvest $(\mathrm{H})$ & 11 & $* *$ & $* *$ & NS & $*$ & $*$ & NS & $* *$ & $* *$ & $* *$ & $* *$ \\
\hline & $\mathrm{Y} \times \mathrm{H}$ & 11 & $* *$ & $* *$ & $* *$ & $* *$ & $* *$ & $* *$ & $* *$ & $* *$ & $* *$ & $* *$ \\
\hline & $\mathrm{C} \times \mathrm{H}$ & 11 & NS & NS & NS & NS & NS & NS & NS & NS & NS & NS \\
\hline & $\mathrm{Y} \times \mathrm{C} \times \mathrm{H}$ & 11 & $* *$ & NS & NS & $* *$ & $* *$ & $*$ & $* *$ & $* *$ & $* *$ & NS \\
\hline \multirow[t]{7}{*}{ B } & Year (Y) & 1 & $* *$ & $* *$ & $* *$ & $* *$ & $* *$ & $* *$ & $* *$ & NS & $* *$ & NS \\
\hline & Cultivar (C) & 1 & $* *$ & $* *$ & NS & $* *$ & NS & $* *$ & NS & $*$ & NS & NS \\
\hline & $\mathrm{Y} \times \mathrm{C}$ & 1 & NS & NS & $*$ & NS & $* *$ & NS & $*$ & NS & $* *$ & NS \\
\hline & Harvest $(\mathrm{H})$ & 11 & $* *$ & $* *$ & $*$ & $* *$ & NS & $*$ & $* *$ & $* *$ & $* *$ & $* *$ \\
\hline & $\mathrm{Y} \times \mathrm{H}$ & 11 & $* *$ & $* *$ & $* *$ & $* *$ & NS & $* *$ & $* *$ & $* *$ & $* *$ & $* *$ \\
\hline & $\mathrm{C} \times \mathrm{H}$ & 11 & $* *$ & NS & NS & NS & $* *$ & NS & NS & NS & NS & NS \\
\hline & $\mathrm{Y} \times \mathrm{C} \times \mathrm{H}$ & 11 & $* *$ & $* *$ & $* *$ & $* *$ & $* *$ & $* *$ & $* *$ & $* *$ & $* *$ & $* *$ \\
\hline \multirow[t]{7}{*}{$C C$} & Year (Y) & 1 & $* *$ & $* *$ & $* *$ & $* *$ & $* *$ & $* *$ & $* *$ & $* *$ & $* *$ & $* *$ \\
\hline & Cultivar (C) & 1 & NS & $* *$ & NS & NS & NS & NS & NS & NS & NS & $* *$ \\
\hline & $\mathrm{Y} \times \mathrm{C}$ & 1 & NS & NS & NS & NS & NS & NS & NS & NS & NS & NS \\
\hline & Harvest $(\mathrm{H})$ & 11 & $* *$ & $* *$ & $* *$ & $* *$ & $* *$ & $* *$ & $* *$ & $* *$ & $* *$ & $* *$ \\
\hline & $\mathrm{Y} \times \mathrm{H}$ & 11 & $* *$ & $* *$ & $* *$ & $* *$ & $* *$ & $* *$ & $* *$ & $* *$ & $* *$ & $* *$ \\
\hline & $\mathrm{C} \times \mathrm{H}$ & 11 & NS & NS & NS & NS & NS & NS & NS & NS & NS & NS \\
\hline & $\mathrm{Y} \times \mathrm{C} \times \mathrm{H}$ & 11 & $* *$ & $*$ & $* *$ & $* *$ & $* *$ & $* *$ & $* *$ & $* *$ & $*$ & $*$ \\
\hline
\end{tabular}

$\dagger$ Cutting treatments: A) sixth internode elongation; B) early flowering; C) uncut control.

Level of significance: NS, not significant; * $\mathrm{P} \leq 0.05 ; * * \mathrm{P} \leq 0.01$.

\subsection{Neutral detergent fibre concentration}

Trends for total, and leaf and stem NDF concentration, during the growing season, were similar for both genotypes. However, the cultivar "Sacromonte" almost always had lower values than "Giza 10" on all cutting treatments (Fig. 1). In the uncut control treatment $(\mathrm{C})$, mean NDF concentration of total herbage increased until the harvests $4-5$, when it reached the maximum values, then plateaued until the late seed pod stage (harvests 10-12). In this treatment, maximum values of NDF were 540 and $515 \mathrm{~g}$ $\mathrm{kg}^{-1}$ DM for cultivars Giza 10 and Sacromonte, respectively, and were reached when plants reached $90 \%$ of their maximum height (Fig. 2) and when leaf-stem ratio (LSR) reached minimum values (0.30, on average; De Santis et al., 2004). The increase in NDF of leaves and stems of both cultivars were similar, but the NDF concentration of the stem is already higher than the NDF concentration of the leaf before the plant reached an advanced stage of maturity (Fig. 1). Mean NDF of leaf increased from 325 to $490 \mathrm{~g}$ $\mathrm{kg}^{-1} \mathrm{DM}$, during the growing season, while mean
NDF of stem significantly increased $(\mathrm{P}<0.05)$ from 484 to $680 \mathrm{~g} \mathrm{~kg}^{-1} \mathrm{DM}$ (Fig. 1). Although the increase in NDF concentrations of the stem with age was lower $(41 \%)$ than that of the leaf (51\%), due to the large contribution of the stem to total herbage dry matter accumulation of both cultivars $(58 \%$, on average; De Santis et al., 2004), NDF concentration of the stem fraction was the primary factor influencing herbage NDF concentration during most of the growing season. These results coincide with those reported by Brink and Fairbrother, 1994, for berseem and red clover.

The NDF concentrations of total herbage, and leaf and stem of berseem were strongly influenced by the cutting treatments. As expected, there was a significant $(\mathrm{P}<0.05)$ reduction in herbage NDF concentration under both treatments A and B (Fig. 1). The treatment B almost always revealed higher NDF values than treatment A, both at cutting time (Tab. 2) and during the growing season (Fig. 1), with no significant differences between cultivars. As for the control treatment, in defoliated plants, the NDF 
(a)
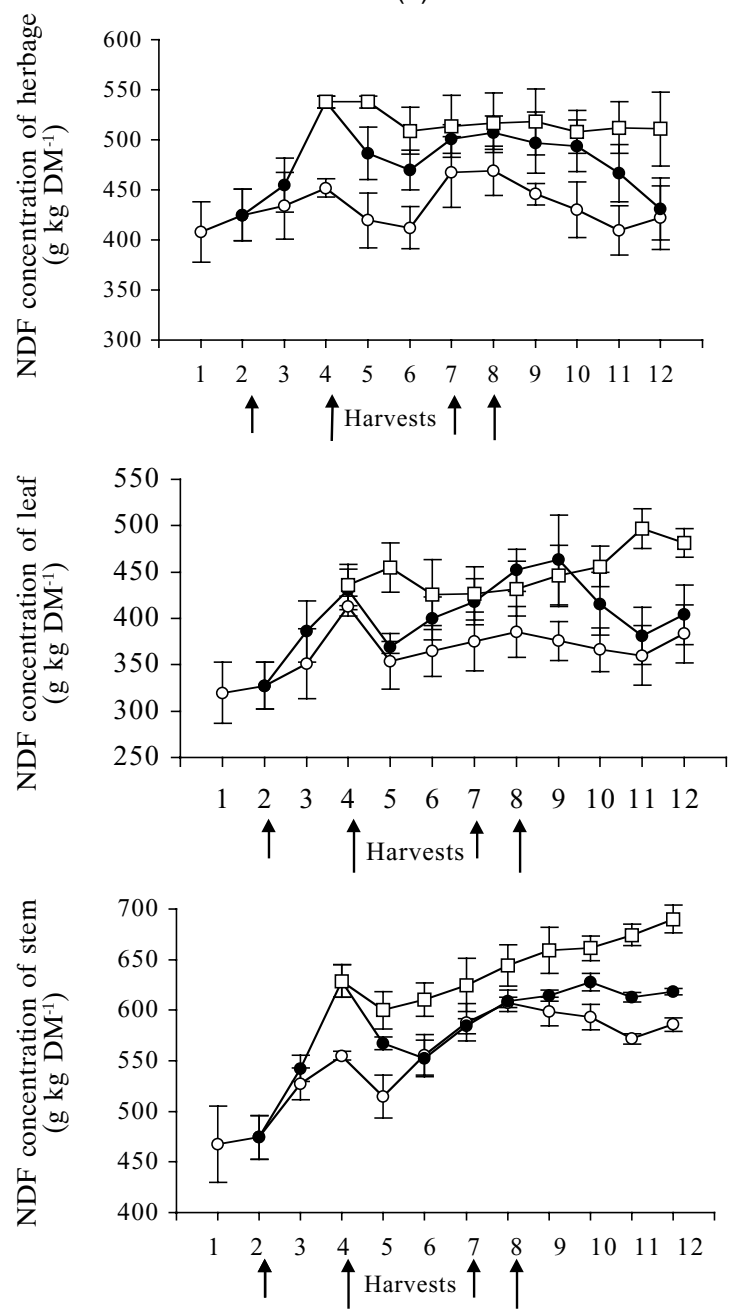

(b)
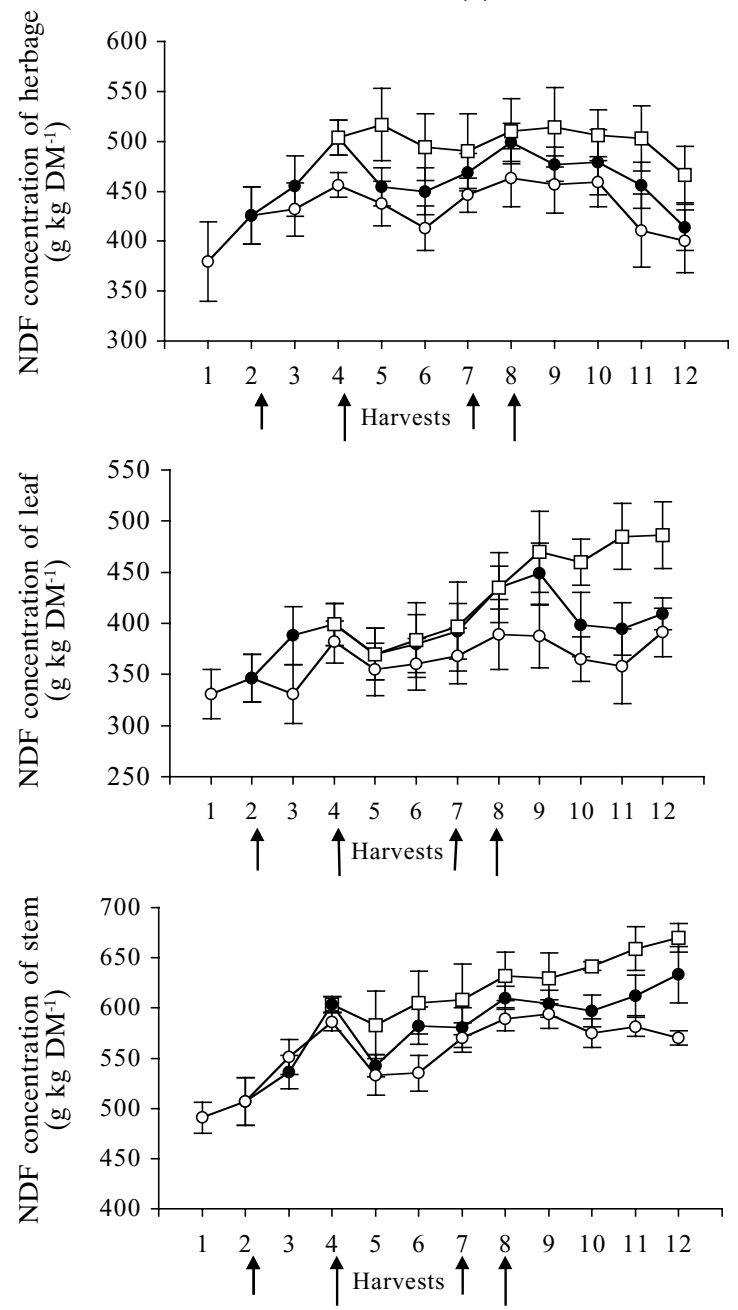

Figure 1. Neutral detergent tibre (NDF) ot herbage, leat and stem components, for (a) cultivar Giza 10 and (b) cultivar Sacromonte under three cutting treatments (o-o, sixth internode elongation; $\bullet-\bullet$ early flowering; $\square-\square$, uncut control) during the experimental period. Means are for 2 years. Vertical bars indicate s.e.m. Arrows indicate the dates of cutting for treatment $\mathrm{A}(\uparrow)$ and $\mathrm{B}(\uparrow)$.

(a)

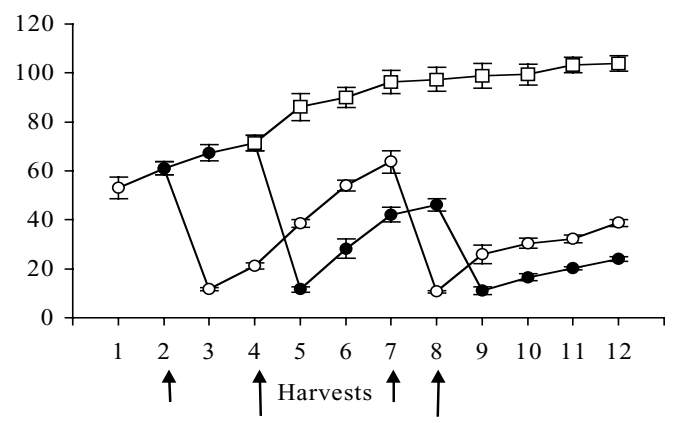

(b)

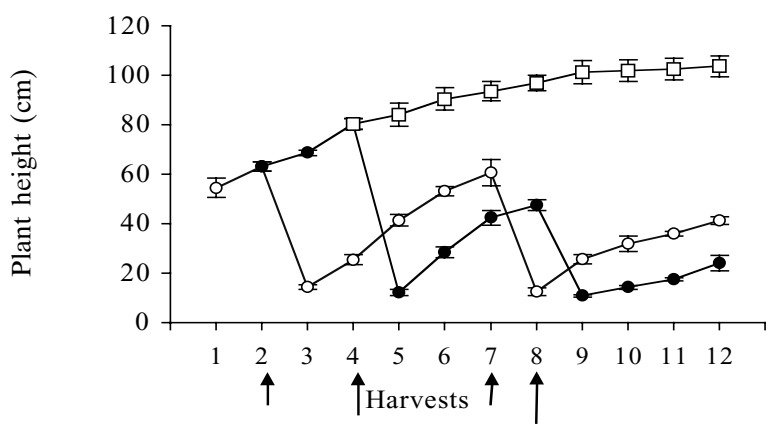

Figure 2. Plant height for (a) cultivar Giza 10 and (b) cultivar Sacromonte under three cutting treatments (o-o, sixth internode elongation; --๑, early flowering; $\square-\square$, uncut control) during the experimental period. Means are for 2 years. Vertical bars indicate s.e.m. Arrows indicate the dates of cutting for treatment A $(\uparrow)$ and B ( $\uparrow)$. 
Table 2. Neutral detergent fibre (NDF), acid detergent fibre (ADF) and acid detergent lignin (ADL) concentrations for total herbage (W), leaf (L) and stem (S) components and plant height at harvests 1 and 2 for Giza 10 and Sacromonte under two cutting treatments combined over two years.

\begin{tabular}{|c|c|c|c|c|c|c|c|c|c|c|c|c|}
\hline \multirow[b]{2}{*}{ Treatment $\dagger$} & \multirow[b]{2}{*}{ Cultivar } & \multirow[b]{2}{*}{ Cut } & \multicolumn{3}{|c|}{$\begin{array}{c}\mathrm{NDF} \\
\left(\mathrm{g} \mathrm{kg}^{-1} \mathrm{DM}\right)\end{array}$} & \multicolumn{3}{|c|}{$\begin{array}{c}\mathrm{ADF} \\
\left(\mathrm{g} \mathrm{kg}^{-1} \mathrm{DM}\right)\end{array}$} & \multicolumn{3}{|c|}{$\begin{array}{c}\mathrm{ADL} \\
\left(\mathrm{g} \mathrm{kg}^{-1} \mathrm{DM}\right)\end{array}$} & \multirow[t]{2}{*}{$\begin{array}{l}\text { Plant } \\
\text { height } \\
(\mathrm{cm})\end{array}$} \\
\hline & & & $\mathrm{W}$ & $\mathrm{L}$ & $\mathrm{S}$ & $\mathrm{W}$ & $\mathrm{L}$ & $S$ & $\mathrm{~W}$ & $\mathrm{~L}$ & $\mathrm{~S}$ & \\
\hline \multirow[t]{2}{*}{$\bar{A}$} & Giza 10 & 1 & 407 & 327 & 474 & 283 & 208 & 347 & 58.34 & 51.88 & 63.62 & 61.07 \\
\hline & Sacromonte & & 431 & 347 & 507 & 283 & 211 & 367 & 57.41 & 47.08 & 66.68 & 63.12 \\
\hline \multirow[t]{2}{*}{$\mathrm{B}$} & Giza 10 & 1 & 539 & 431 & 629 & 375 & 275 & 459 & 83.28 & 69.22 & 95.04 & 71.30 \\
\hline & Sacromonte & & 505 & 399 & 604 & 373 & 268 & 458 & 74.26 & 55.55 & 89.48 & 80.28 \\
\hline \multicolumn{13}{|c|}{ Level of significance } \\
\hline \multicolumn{3}{|c|}{ Cultivar (C) } & NS & NS & NS & NS & NS & NS & NS & NS & NS & $* *$ \\
\hline \multicolumn{3}{|l|}{ Treatment (T) } & $* *$ & $* *$ & $* *$ & $* *$ & $* *$ & $* *$ & NS & $* *$ & $* *$ & $* *$ \\
\hline \multicolumn{3}{|l|}{$\mathrm{C} \times \mathrm{T}$} & NS & $* *$ & NS & NS & NS & NS & $*$ & NS & NS & $* *$ \\
\hline \multirow[t]{2}{*}{ A } & Giza 10 & 2 & 468 & 375 & 588 & 325 & 228 & 446 & 60.30 & 45.28 & 80.95 & 63.65 \\
\hline & Sacromonte & & 446 & 368 & 571 & 347 & 254 & 442 & 68.06 & 52.42 & 85.30 & 60.65 \\
\hline \multirow[t]{2}{*}{$\mathrm{B}$} & Giza 10 & 2 & 492 & 452 & 609 & 359 & 230 & 452 & 75.50 & 52.74 & 88.38 & 46.00 \\
\hline & Sacromonte & & 499 & 435 & 610 & 327 & 249 & 457 & 65.70 & 49.57 & 87.44 & 47.47 \\
\hline \multicolumn{13}{|c|}{ Level of significance } \\
\hline \multicolumn{3}{|c|}{ Cultivar (C) } & NS & NS & NS & NS & NS & NS & NS & $*$ & NS & NS \\
\hline \multicolumn{3}{|l|}{ Treatment $(\mathrm{T})$} & $* *$ & $* *$ & $* *$ & NS & NS & NS & NS & NS & $*$ & $* *$ \\
\hline \multicolumn{3}{|l|}{$\mathrm{C} \times \mathrm{T}$} & NS & $* *$ & NS & $*$ & $* *$ & NS & $*$ & $* *$ & NS & NS \\
\hline
\end{tabular}

$\dagger$ Cutting treatments: A, sixth internode elongation; B, early flowering.

Level of significance: NS, not significant; $* \mathrm{P} \leq 0.05 ; * * \mathrm{P} \leq 0.01$.

values of the leaves were lower than those of the stems for both cultivars.

\subsection{Plant height}

As expected, control plants showed a continual increase $(\mathrm{P}<0.05)$ in plant height with advancing maturity, approximately from 50 to $105 \mathrm{~cm}$ (Fig. 2), and always had higher values than defoliate plants. A rapid regrowth was observed after cuttings, for both cultivars, and the same value was reached in both cuts in treatment $A$ (about $62 \mathrm{~cm}$ ), whereas plants were higher in the first than in the second cut under treatment B (75 and $47 \mathrm{~cm}$, respectively), indicating that the cut applied at the early flowering stage significantly reduced regrowth height. This is in accordance with McDonald et al. (1995), which stated that the rate of regrowth depends upon the maturity of the crop at the time of harvesting. If the crop is harvested when it is young and leafy it recovers more quickly and starts regrowth earlier than when a more mature herbage is harvested.

\subsection{Acid detergent fibre concentration}

Linear trends for ADF concentration of total forage and leaf and stem of both cultivars were similar to changes observed in NDF concentration during the growing season (Fig. 3). As expected, mean ADF concentration of the two cultivars increased with advancing plant maturity (treatment C). In this treatment, the increase in ADF concentration of stem was similar to that of leaves, but the ADF concentrations of the stems were double than those found for leaf, ranging from 340 to $510 \mathrm{~g} \mathrm{~kg}^{-1} \mathrm{DM}$ compared with 195 to $340 \mathrm{~g} \mathrm{~kg}^{-1} \mathrm{DM}$ for ADF concentration of leaf. As for the results observed for NDF, accumulation of stem DM (De Santis et al., 2004) and increase in ADF concentration of stem were probably the primary factors influencing ADF concentration of the total forage.

The development stage at cutting greatly influenced the ADF concentrations of total herbage, and leaf and stem (Fig. 3). For both cultivars, the treatment $\mathrm{B}$ revealed higher ADF values than treatment $A$ only at the first cut, when the differences between treatments were $30 \%$ for all fractions (Tab. 2). As for the NDF, in defoliated plants, ADF concentration of leaf was lower than that of stem throughout the sampling period, reaching a maximum value of $265 \mathrm{~g} \mathrm{~kg}^{-1} \mathrm{DM}$, on average, at harvest 4 in both treatments, for both cultivars (Fig. 3). 
(a)
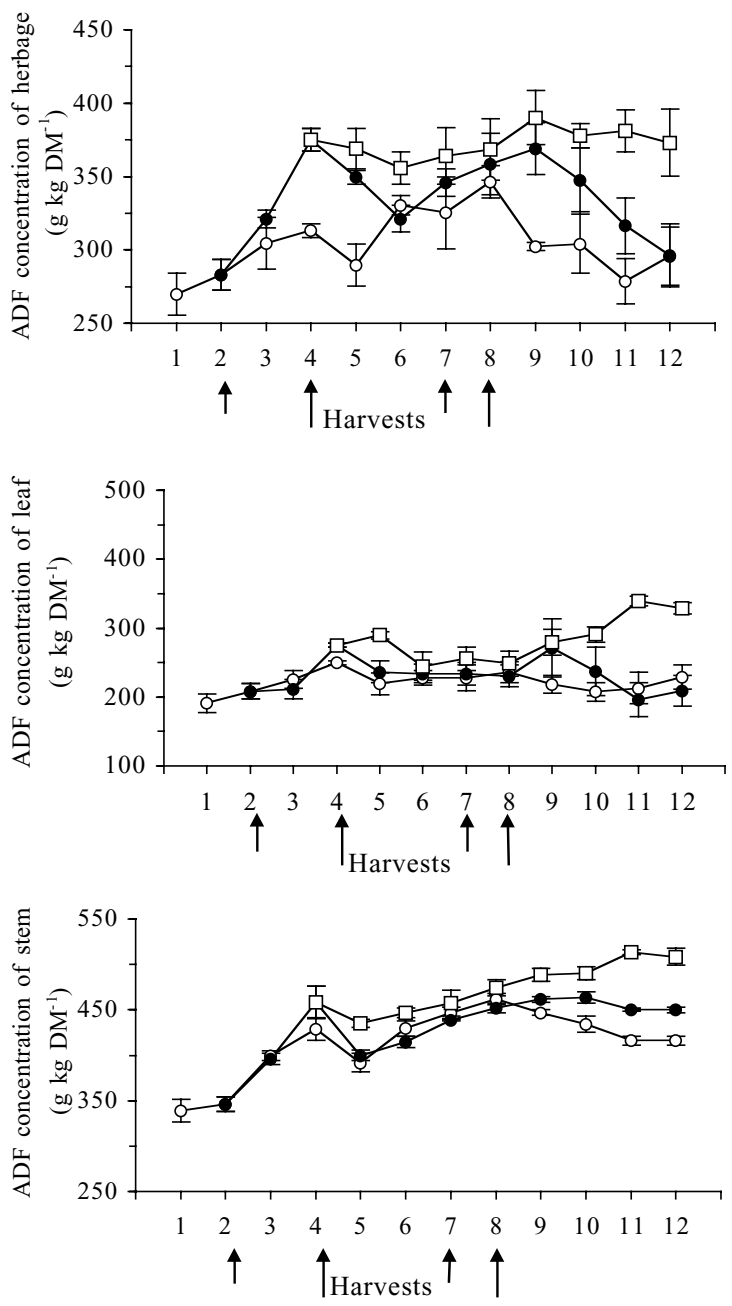

(b)
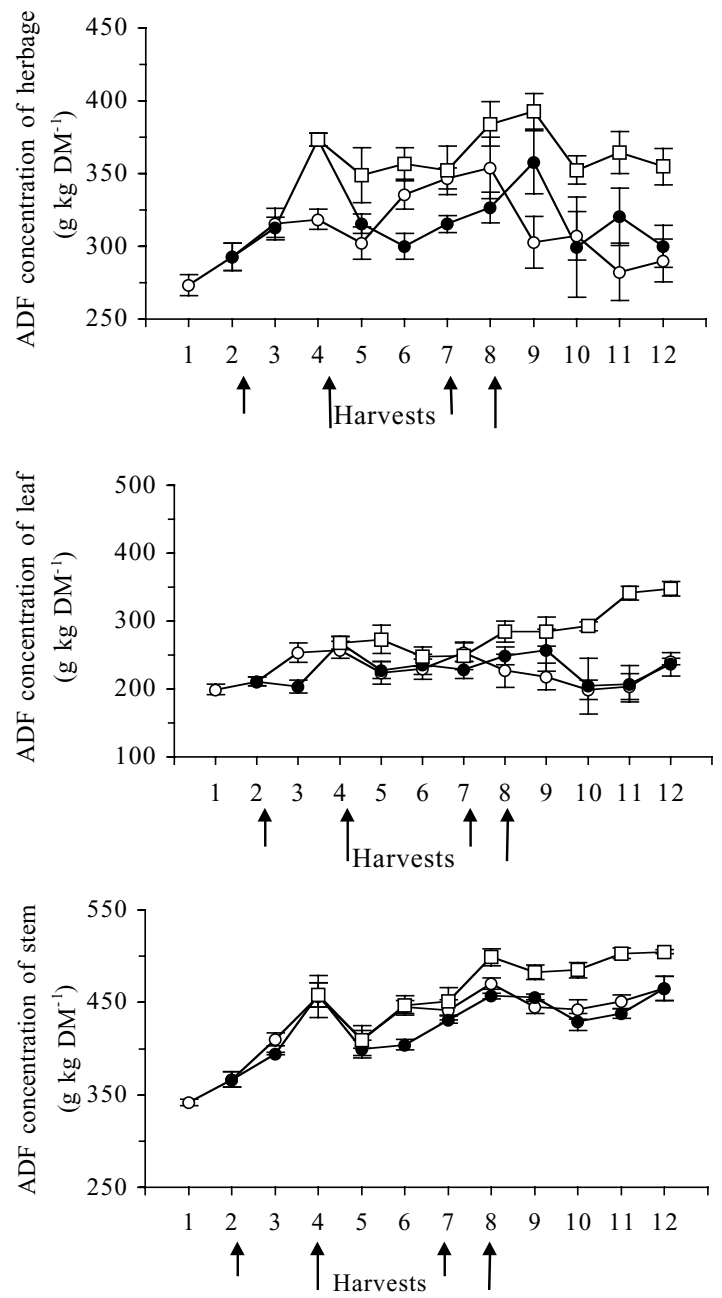

Figure 3. Acid detergent fibre (ADF) of herbage, leaf and stem components, and plant height, for (a) cultivar Giza 10 and (b) cultivar Sacromonte under three cutting treatments (o-o, sixth internode elongation; $\bullet-\bullet$, early flowering; $\square-\square$, uncut control) during the experimental period. Means are for 2 years. Vertical bars indicate s.e.m. Arrows indicate the dates of cutting for treatment $\mathrm{A}(\uparrow)$ and $\mathrm{B}(\uparrow)$.

\subsection{Acid detergent lignin concentration}

In treatment $(\mathrm{C})$, mean $\mathrm{ADL}$ concentration of total herbage significantly $(\mathrm{P}<0.05)$ increased with time, as the plant advanced to maturity. In this treatment, maximum values of $\mathrm{ADL}$ were $83 \mathrm{~g} \mathrm{~kg}^{-1} \mathrm{DM}$, on average, for both cultivars, and were reached at harvests $10-12$, when plant height also reached maximum values (105 cm, on average). The increase in ADL concentration of leaves and stems of both cultivars were similar. Mean ADL of leaf increased from 41 to $79 \mathrm{~g} \mathrm{~kg}^{-1} \mathrm{DM}$, during the growing season, while mean ADL of stem increased from 60 to $112 \mathrm{~g} \mathrm{~kg}^{-1}$ DM (Fig. 4).

The ADL concentration of total herbage and leaf and stem were affected by cutting treatments (Fig. 4). The treatment B revealed higher ADL values than treatment $A$, both at cutting time and during the growing season (Tab. 2). At the first cut the differences in ADL concentration between treatments were $27 \%$ for herbage and leaf and $42 \%$ for stem (Tab. 2). These differences, even if slightly lower, also occurred at the second cut, for the total herbage (19\%) and stem (6\%). 
(a)
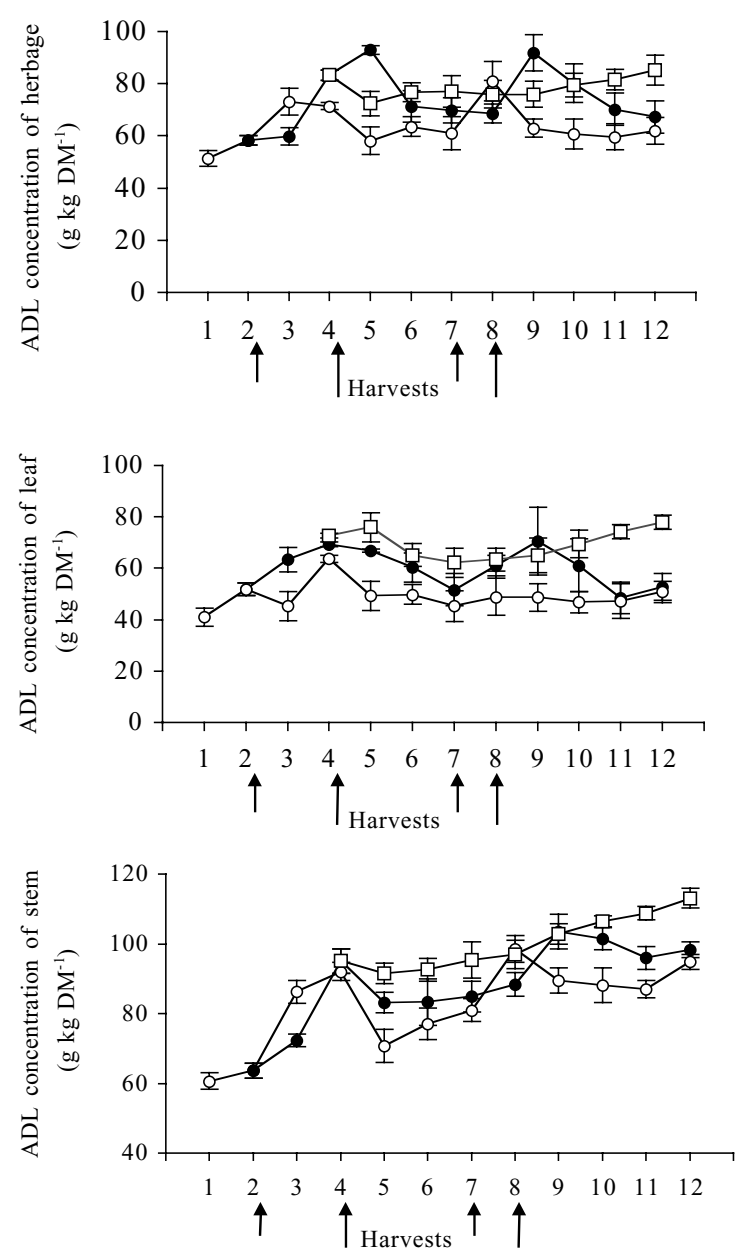

(b)
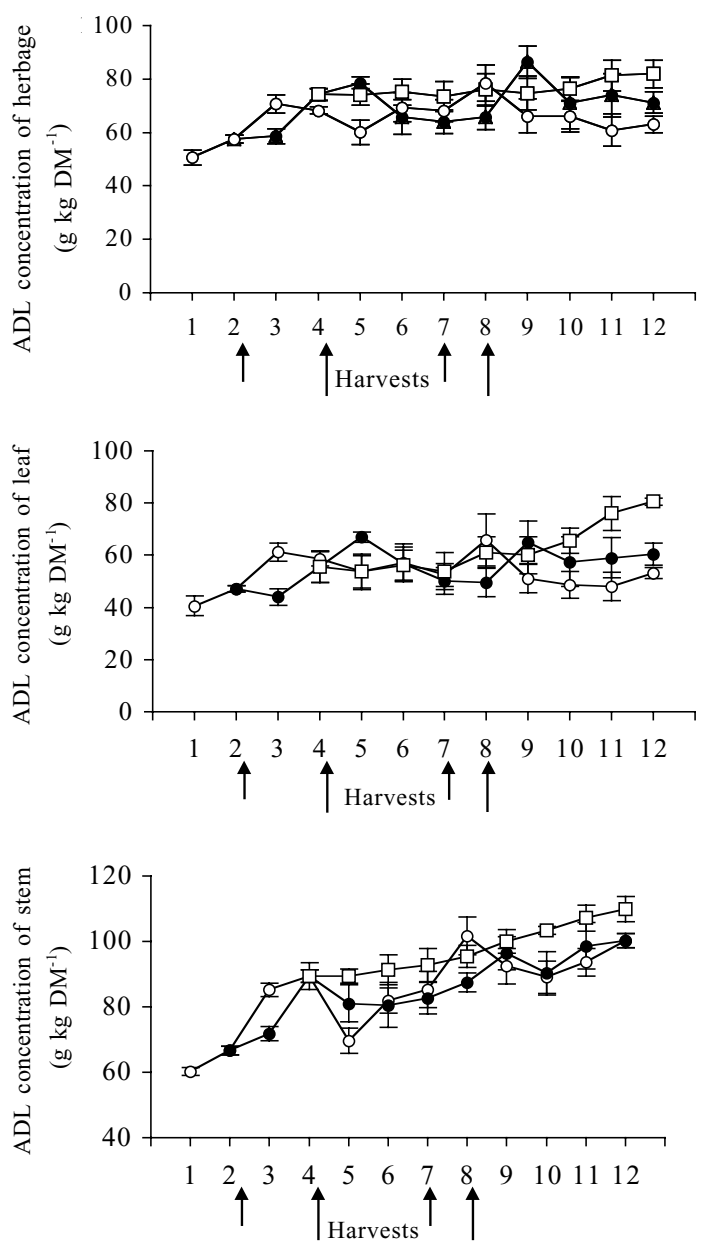

Figure 4. Acid detergent lignin (ADL) of herbage, leaf and stem components, and plant height, for (a) cultivar Giza 10 and (b) cultivar Sacromonte under three cutting treatments (o-o, sixth internode elongation; $\bullet-\bullet$, early flowering; $\square$ - $\square$, uncut control) during the experimental period. Means are for 2 years. Vertical bars indicate s.e.m. Arrows indicate the dates of cutting for treatment $\mathrm{A}(\uparrow)$ and $\mathrm{B}(\uparrow)$.

Table 3. Correlation coefficients between in vitro organic matter digestibility (IVOMD) (De Santis et al., 2004), plant height $(\mathrm{PH})$, leaf stem ratio (LSR) and herbage and leaf and stem fibre components (NDF, ADF, and ADL) concentrations for each cutting treatment combined over cultivars and years $(\mathrm{n}=48)$.

\begin{tabular}{|c|c|c|c|c|c|c|c|c|c|c|}
\hline \multirow[b]{2}{*}{ Trait } & \multirow[b]{2}{*}{ Treatment $^{\dagger}$} & \multicolumn{3}{|c|}{ Herbage } & \multicolumn{3}{|c|}{ Leaf } & \multicolumn{3}{|c|}{ Stem } \\
\hline & & $\mathrm{NDF}$ & $\mathrm{ADF}$ & ADL & $\mathrm{NDF}$ & $\mathrm{ADF}$ & ADL & NDF & $\mathrm{ADF}$ & ADL \\
\hline \multirow[t]{3}{*}{ IVOMD } & A & -0.19 & -0.10 & -0.38 & -0.32 & -0.05 & -0.38 & $-0.86 * *$ & $-0.85 * *$ & $-0.95 * *$ \\
\hline & $\mathrm{B}$ & -0.26 & -0.21 & -0.28 & -0.26 & $-0.42 *$ & -0.04 & $-0.89 * *$ & $-0.89 * *$ & $-0.95 * *$ \\
\hline & $\mathrm{C}$ & $-0.52 * *$ & $-0.69 * *$ & $-0.78 * *$ & $-0.94 * *$ & $-0.94 * *$ & $-0.90 * *$ & $-0.91 * *$ & $-0.90 * *$ & $-0.96 * *$ \\
\hline \multirow[t]{3}{*}{$\mathrm{PH}$} & A & -0.33 & -0.24 & -0.04 & -0.40 & -0.29 & 0.04 & -0.40 & -0.35 & -0.11 \\
\hline & B & -0.39 & -0.34 & -0.16 & -0.28 & -0.04 & -0.32 & $-0.50 *$ & $-0.45 *$ & $-0.44 *$ \\
\hline & $\mathrm{C}$ & $0.75^{* *}$ & $0.86^{* *}$ & $0.77 * *$ & $0.88 * *$ & $0.84 * *$ & $0.76 * *$ & $0.94 * *$ & $0.94 * *$ & $0.93 * *$ \\
\hline \multirow[t]{3}{*}{ LSR } & A & 0.13 & 0.11 & 0.27 & & & & & & \\
\hline & B & 0.19 & 0.17 & 0.14 & & & & & & \\
\hline & $\mathrm{C}$ & $-0.56 * *$ & $-0.72 * *$ & $-0.81 * *$ & & & & & & \\
\hline
\end{tabular}

$\dagger$ Cutting treatment: A, sixth internode elongation; B, early flowering; C, uncut control.

Level of significance: $* \mathrm{P}<0.05, * * \mathrm{P}<0.01$. 


\subsection{Correlations of IVOMD, plant height and LSR with fibre components}

With few exceptions, herbage and leaf and stem IVOMD values reported previously (De Santis et al., 2004) were negatively correlated with NDF, ADF and ADL concentrations for all cutting treatments (Tab. 3). However, these negative correlations were generally highly significant in treatment $\mathrm{C}$, but poor or non-significant in treatment $\mathrm{A}$, for herbage and leaf fraction. This indicates that berseem clover plants cut at an early stage of growth, more digestible (De Santis et al., 2004), also have a lower concentration of fibre components. However, the IVOMD values of stem fraction resulted always highly negatively correlated with all fibre components for all cutting treatments, indicating that stems are the lowest quality part of the forage plant fraction which more contributes to decreased the forage digestibility in all cutting treatments.

In agreement with different authors for other species (Kephart et al., 1990; Carpenter and Casler, 1990), the ADL concentration was strongly negatively correlated with IVOMD in all plant fractions, in treatment $\mathrm{C}$, indicating that, this trait, as well as NDF, is an important fibre component statistically related to forage digestibility of berseem clover. In the stem fraction, the highly significant $(\mathrm{P}<0.01)$ and negative correlations of ADL with IVOMD ( $\mathrm{r}=$ -0.95 , on average) further supports the view that lignin depressed the digestibility of berseem clover.

The plant height was negatively correlated with fibre components of stem fraction in treatments $\mathrm{A}$ and $\mathrm{B}$, and positively with fibre components of all fractions, in treatment C (Tab. 3), indicating that, without defoliation, there is a greater accumulation of the fibre components, due to a high concentration of lignin.

As axspected, the LSR was negatively associated with herbage NDF, ADF and ADL concentrations, in treatment $\mathrm{C}(r=-0.70$, on average) but not in treatments $\mathrm{A}$ and $\mathrm{B}$ (Tab. 3 ). These results indicate that, cutting treatment had a great influence on accumulation of plant fibre components and that part of the change in fibre components of berseem clover plants is due primarily to the changes in the leaf-stem ratio.

\section{Discussion}

As with dry matter partitioning and forage quality (Iannucci, 2001; De Santis et al., 2004), the results of this study indicate that cutting treatment and development stage at cutting had the greatest effects on the cell wall components of berseem clover. Our previous data showed that, in defoliated plants, both IVOMD and CP values of total herbage increased as leaf-stem ratio increased. Conversely, in the control undefoliated plants, with advancing maturity, values of these traits rapidly declined because of a reduction in the LSR with a consequent increase in the proportion of stem. The present data show that without defoliation plants showed a rapid increase in fibre (NDF, ADF and ADL) concentrations, during the growing period. Plant height continually increased with advancing maturity, whereas the ratio of leaf to stem decreased in the same period (from 1.00 to 0.35 , approximately; De Santis et al. 2004). Thus, in agreement with different authors (Buxton and Russell, 1988; Kepart et al., 1989, 1990; Brink and Fairbrother, 1994; Lloveras and Iglesias, 2001), the increase in fibre concentrations of total herbage with advancing maturity was mainly due to a reduction in the leaf-stem ratio and in the increase of the fibre values of stem. Conversely, defoliation induced a reduction in fibre concentrations and plant height, and increased the regrowth, in both treatments A and B. Furthermore, this regrowth was accompanied by higher values of LSR and consequent higher values of IVDOM and CP than in the control undefoliated plants (De Santis et al., 2004). This confirms, according to Iannucci (2001), that berseem clover is a defoliation-tolerant species that can produce a regrowth with a higher nutritive value (Shrestha et al., 1998).

The current study presents quantitative evidence to indicate that the cut applied at the sixth internode elongation is better than that at early flower, for growth and forage fibre contents of berseem clover grown in Mediterranean regions. At the sixth internode stage, the plants had lower fibre concentrations and higher regrowth height, compared with the plants cut at early flowering stage (B). Previously we reported (De Santis et al., 2004) that early cutting produced higher quality traits than late cutting: harvesting the first growth later (treatment B) gave 
higher total forage yields (about 17\%) for the season than did earlier harvests (treatment A) but resulted in herbage with lower digestibility and crude protein concentration, as a result of the increase in the stem fraction. Furthermore, due to the inverse relationship between the stage of growth at cutting and the DM yield in the regrowth, the cut applied at the early flowering stage decreased the DM yield in the regrowth (Iannucci, 2001). Thus, the lower total yield with earlier harvests was partially offset by higher forage quality of spring growth and greater availability of regrowth herbage having lower fibre contents, in late summer. Similar results have been reported for other plant species (Pohlmann and Simon, 1993; Xia et al., 1993; Gustavsson and Martinsson, 2004). Therefore, harvest management in which cuts are applied at the stage of plant development corresponding to sixth internode elongation seems to be an acceptable compromise for harvesting a forage with acceptable yield, higher digestibility and crude protein concentration, and lower fibre content.

After cutting, in both treatments A and B, the production of new leaves led to increased the leaf-stem ratio (Iannucci, 2001; De Santis et al., 2004) and in agreement with Kepart et al. (1990), decreased lignin concentration by dilution of stem cell walls in the total herbage. This explains the negative correlations between plant height and fibre components obtined in defoliated plants. Conversely, in treatment $\mathrm{C}$, the highly significant and positive correlations between plant height and fibre components were due to higher concentrations of cell wall costituents in the control plants.

Furthermore, without defoliation there was a greater lignin accumulation and a lower leafstem ratio (De Santis et al., 2004). Thus, in treatment $\mathrm{C}$, the highly significant and negative correlations between LSR and herbage NDF, ADF and ADL concentrations, suggested that, in berseem clover, as in other forage legumes, such as alfalfa, birdsfoot trefoil, red and crimson clover (Buxton et al., 1985; McGraw and Marten, 1986; Lloveras and Iglesias, 2001), a higher leaf-stem ratio is consistently associated with a lower forage cell wall concentration.

Under treatments A and B for both cultivars, the decrease in herbage NDF, ADF and ADL concentrations, due to defoliation, was pri- marily as a result of an increase in the leaf-stem ratio (from 1.0 to 2.5, approximately; De Santis et al., 2004). In agreement with other authors (Albrecht et al., 1987; Kepart et al., 1989) this trait is greatly affected by maturity, as evidenced by the highly negative correlation with the DM yield, in the uncut treatment $\mathrm{C}$, previously reported (-0.95; De Santis et al., 2004). This indicates that an increase, even if small, in forage yield, as obtained under treatment B (De Santis et al., 2004), is correlated with an increase in stem fraction, which usually has relatively low values of IVOMD and CP concentration, and high fibre concentrations. However, Minson (1983) provided evidence that the quantity and quality of the leaf fraction may be more important than the total forage quantity and quality under some grazing conditions, because where there are large quality differences between leaves and stems in a pasture, animals prefer to eat the leaf.

The results of this study confirm that due to the relatively small changes in cell wall concentration of the leaf fraction and equivalent DM accumulation patterns (De Santis et al., 2004), minimal quality differences exist between the two cultivars during the growing season in relation to harvest management, in terms both of production and forage nutritive value.

The previous (De Santis et al., 2004) study has demonstrated that based on the DM accumulation, high ratios of the leaf-to-stem tissue, and nutrient concentration patterns of the leaf fraction of the two cultivars examined, in a Mediterranean context, berseem clover can provide forage of good quality throughout the spring growth period. This legume, when harvested at the sixth internode elongation, can be a very high-quality alternative forage in southern Italian environmental conditions, because it is caracterized by a rapid regrowth after cutting, accompanied by high values of LSR, high digestibility and low fibre content.

\section{References}

Albrecht K.A., Wedin W.F., Buxton D.R. 1987. Cell-wall composition and digestibility of alfalfa stems and leaves. Crop Sci., 27:735-741.

Brink G.E., Fairbrother T.E. 1994. Cell wall composition of diverse clovers duringprimary spring growth. Crop Sci., 34:1666-1671. 
Buxton D.R., Hornstein J., Wedin W.F., Marten G. 1985. Forage quality in stratified canopies of alfalfa, birdsfoot trefoil and red clover. Crop Sci., 25:273-279.

Buxton D.R., Hornstein J.S. 1986. Cell wall concentration and components stratified canopies of alfalfa, birdsfoot trefoil and red clover. Crop Sci., 26:180-184.

Buxton D.R., Russel J.R., 1988. Lignin constituents and cell-wall digestibility of grass and legume stems. Crop. Sci., 28:553-558.

Carpenter J.A., Casler M.D. 1990. Divergent phenotypic selection response in smooth bromegrass for forage yield and nutritive value. Crop. Sci., 30:17-22.

Chesson A., Stewart C.S., King Y.P. 1986. Degradation of isolated grass mesophyll, epidermis and fiber cell walls in the rumen and by rumen bacteria. J. Appl.Bacteriol., 60:327-336.

De Santis G., Iannucci A., Dantone D., Chiaravalle E. 2004. Changes during growth in the nutritive value of components of berseem clover (Trifolium alexandrinum L.) under different cutting treatments in a Mediterranean region. Grass Forag. Sci., 59:378-388.

Goering H.K., Van Soest P.J. 1970. Forage fiber analyses (apparatus, reagents,procedures, and some applicatios). USDA ARS, Agric. Handb. 379. US Government Printing Office, Washington DC.

Gustavsson A.-M., Martinsson K. 2004. Seasonal variation in biochemical composition of cell walls, digestibility, morphology, growth and phenology in timoty. Europ. J. Agron., 20:293-312.

Iannucci A., Di Fonzo N., Martiniello P. 1996. Effects of the developmental stage atharvest on dry matter and chemical component partitioning in berseem. J. Agron. Crop Sci.,176:165-172.

Iannucci A. 2001. Effects of harvest management on growth dynamics, forage and seedyield in berseem clover. Europ. J. Agron., 14:303-314.

Jung H.G., Vogel K.P. 1992. Lignification of switchgrass (Panicum virgatum) andbig bluestem (Andropogon gerardii) plant parts during maturation and its effect on fibre degradability. J. Sci. Food Agric., 59:69-176.

Kephart K.D., Buxton D.R., Hill R.R. Jr. 1989. Mor- phology of alfalfa selected for divergent herbage lignin concentration. Crop sci., 29:778-782.

Kephart K.D., Buxton D.R., Hill R.R. Jr. 1990. Digestibility and cell-wallcomponents of alfalfa following selection for divergent herbage ligninconcentration. Crop Sci., 30:207-212.

Lloveras J., Iglesias I. 2001. Morphological development and forage quality changes in crimson clover (Trifolium incarnatum L.). Grass Forage Sci., 56:395-404.

Marten G.C., Brink G.E., Buxton D.R., Halgerson J.L., Hornstein J.S. 1984. Nearinfrared reflectance spectroscopy analysis of forage quality in four legume species. Crop Sci., 24:1179-1182.

McDonald P., Edvards R.A., Greenhalgh J.F.D., Morgan C.A. 1995. Animal Nutrition, $5^{\text {th }}$ ed. Longman Scientific and Technical, Essex, UK.

McGraw R.L., Marten G.C. 1986. Analysis of primary growth of four pasture legume species. Agron. J., 78:704-710.

Minson D.J. 1983. Forage quality: Assessing the plantanimal complex. XIV International Grassland Congress, Lexington, 23-29.

Pohlmann W., Simon U. 1993. Effects of cutting dates in primary growth, water soluble carboydrate content, and nitrogen fertilisation on regrowth of perennial rygrass. Proceedings of the $17^{\text {th }}$ International Grassland Congress, Palmerston North, New Zeland, 171-172.

Shenk J.S., Westerhaus M.O. 1991. Population structuring of near infrared spectra and modified partial least squares regression. Crop Sci., 3:1548-1555.

Shrestha A., Hesterman O.B., Squire J.M., Fisk J.W., Sheaffer C.C. 1998. Annual Medics and Berseem Clover as Emergency Forages. Agron. J., 90:197-201.

Steel R.G.D., Torrie J.H. 1980. Principles and procedures of statistics: A biometricaln approach. $2^{\text {nd }}$ ed. McGraw-Hill, New York.

Xia J.X., Hodgson J., Chiu A.C.P., Wang P., Liu F.Y. 1993. Effects of cutting management on herbage production and tiller population in smooth bromegrass (Bromus inermis Leyss). In: SIR (ed.): Proceedings of the $17^{\text {th }}$ International Grassland Congress, Palmerston North, New Zeland, 151-152. 